\title{
PELAYANAN KAPAL DAN BARANG DI PELABUHAN CILACAP
}

\author{
Bambang Sudjasta \\ Program Studi Teknik Perkapalan-Fakultas Teknik, UPN “Veteran” Jakarta, Jakarta Selatan, Indonesia \\ email: karebet_m@yahoo.co.id
}

\begin{abstract}
Port of Cilacap is currently the only port of the ocean, located on the south coast of Java, so its position is strategic to support marine transportation system, where westward the island of Sumatera, South Asia, and the Middle East, to the east is Nusatenggara, and until the Australian continent. Cilacap port has a support area (hinterland) potential, namely the southern part of Central Java, Yogyakarta and West Java southeast. Increased support the region's economy will lead to increased trade that will improve the flow of goods/ commodities and the number of ship visits in the port of Cilacap. The number of ship visits dominated by tankers, and commodities trading is dominated by fuel oil. This study aims to conduct a review of port services, especially services to ships and service of loading and unloading of goods that must be continuously improved quality and quantity.
\end{abstract}

Keywords: ship traffic, the flow of goods, port services

\section{PENDAHULUAN}

\section{Latar Belakang}

Indonesia sebagai negara kepulauan, maka transportasi laut menjadi hal yang strategis, sehingga moda transportasi laut menjadi hal yang sangat penting, terutama untuk mengangkut dan mendistribusikan komoditas antar pulau (dalam negeri) maupun kegiatan ekspor-impor (perdagangan luar negeri).

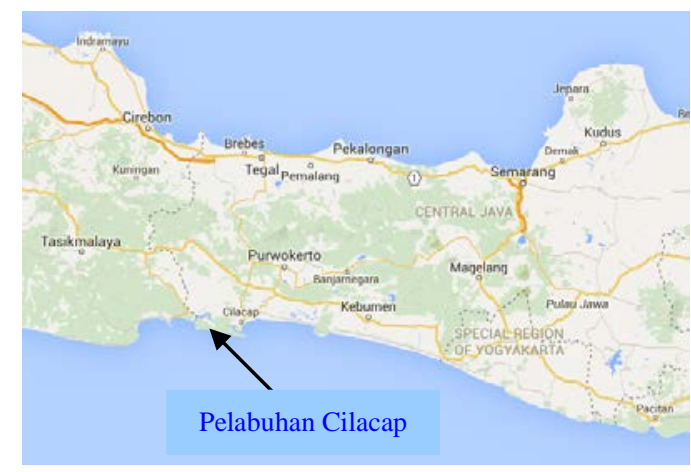

Gambar 1. Lokasi Pelabuhan Cilacap

Pelabuhan Cilacap ditinjau dari letak geografis merupakan satu-satunya pelabuhan samudera yang berlokasi di pantai selatan Pulau Jawa, tepatnya di Kabupaten Cilacap, Jawa Tengah. Kedudukannya sangat strategis sebagai pendukung transportasi laut kearah timur sampai benua Australia, kearah barat yaitu Pulau Sumatera dan Asia Selatan.

\section{Perumusan Masalah}

Permasalahan yang perlu mendapat perhatian:
1) Bagaimana memaksimalkan pelayanan barang khususnya pada pelaksanaan bongkar muat dan penyimpanannya.

2) Bagaimana memaksimalkan pelayanan kapal yang berkunjung dari kapal masuk sampai keluar pelabuhan.

\section{Tujuan Penelitian}

1) Meningkatkan jasa pelayanan kapal yang berkunjung;

2) Meningkatkan jasa pelayanan bongkar-muat barang.

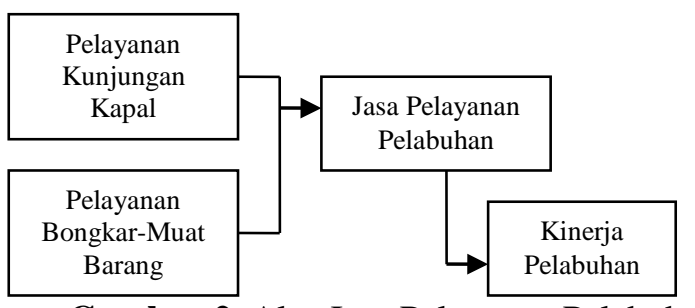

Gambar 2. Alur Jasa Pelayanan Pelabuhan

\section{Tinjauan Pustaka \\ Pengertian Pelabuhan}

Menurut UU No.17 Tahun 2008 tentang Pelayaran, "Pelabuhan adalah tempat yang terdiri atas daratan dan/atau perairan dengan batas-batas tertentu sebagai tempat kegiatan pemerintahan dan kegiatan pengusahaan yang dipergunakan sebagai tempat kapal bersandar, naik turun penumpang, dan/atau bongkar muat barang, berupa terminal dan tempat berlabuh kapal yang dilengkapi dengan fasilitas keselamatan dan keamanan pelayaran dan kegiatan penunjang pelabuhan serta sebagai tempat perpindahan intra-dan antarmoda transportasi”. 
Kondisi fisik pelabuhan: geografis, alur pelabuhan, dan lingkungan daerah kerja pelabuhan. Lalu-lintas pelabuhan: lalu-lintas kunjungan kapal dan lalu-lintas bongkar-muat barang. Produksi jasa pelabuhan: pelayanan jasa kapal dan pelayanan jasa bongkar-muat barang, pengusahaan peralatan, pelayanan terminal. Kinerja pelabuhan: kinerja pelayanan kapal dan barang. Fasilitas dan peralatan pelabuhan: pemanfaatan peralatan, utilisasi dermaga, utilisasi gudang dan peralatan.

\section{Pengertian Pelayanan}

Melayani adalah "membantu menyiapkan (mengurus) apa yang diperlukan seseorang". Sedangkan pelayanan adalah "usaha melayani kebutuhan orang lain” (KBBI, 1995). Pelayanan prima dalam hal ini sesuai dengan harapan pelanggan.

\section{Tipe Muatan}

Muatan dapat dibedakan menurut 2 (dua) sudut pandang:

\section{Kondisi Fisik (Physical State)}

a. Muatan kering (dry cargo)

Kering di sini lebih ditujukan untuk barang belum jadi (mentah) seperti bijih besi, batu bara, biji-bijian, fosfat, bauksit, aluminium, belerang, dan semen. Banyak juga barang-barang setengah jadi maupun jadi yang masuk kategori ini, seperti kayu lapis, barang kelontong dan barang-barang manufaktur.

\section{b. Muatan cair (liquid cargo)}

Muatan ini berbentuk cairan sehingga memerlukan tempat khusus pada saat dikapalkan/ dipindahkan dari suatu tempat ke tempat lain. Komoditi jenis ini seperti minyak mentah, produk berbahan dasar minyak, bahan-bahan kimia, gas yang dicairkan dihasilkan dari eksplorasi minyak bumi (LPG), Gas Alam Cair LNG).

\section{Bentuk Pada Saat Dikapalkan}

Bentuk yang dimaksud adalah volume/ ukuran sampai di mana suatu muatan dapat dikapalkan:

\section{a. Bulk cargo (borongan)}

Muatan yang secara alamiah tidak dapat dipisah-pisahkan/ dibagi-bagi pada saat dibongkat/ muat dari/ ke atas kapal serta tidak memerlukan kemasan atau pembungkus khusus. Muatan jenis ini tidak perlu dihitung ke dalam unit-unit kecil karena dalam sekali pengapalan ia dapat memenuhi ruang palkah. Jadi muatan ini dikapalkan dalam bentuk besar/ borongan yang dibongkar/ muat dengan cara menuangkan, memompa, atau dengan sabuk berjalan.

b. General cargo (campuran)
Muatan bervolume relatif kecil, dapat dihitung ke dalam unit-unit kecil, serta berukuran bervariasi satu dengan yang lain. Muatan jenis ini pada saat dikapalkan ada yang memerlukan kemasan khusus maupun kemasan konvensional yang tidak standar. Muatan yang tidak memerlukan kemasan khusus biasanya dimasukkan ke dalam karung, kantong, kotak karton, bundel, drum, serta kotak kayu. Muatan jenis ini dapat diangkut oleh manusia (berat $\pm 50 \mathrm{~kg}$ per unit) serta memiliki nilai tidak terlalu tinggi.

\section{Efisiensi dan Produktifitas Pelabuhan Indikator Pelayanan}

Menunjukkan efisiensi waktu pelayanan kapal yang didalamnya terdapat unsur pelayanan kapal dan pelayanan bongkar-muat barang di pelabuhan. Indikator yang dipakai adalah Waktu Kapal di Pelabuhan (Ships Turn Round Time/ TR):

1) Waktu Tunggu Kapal di Pelabuhan (Waiting Time/ WT);

2) Waktu kapal di Dermaga (Berth Time/ BT).

\section{Indikator Luaran (Output)}

Menunjukkan besaran luaran dari proses pelayanan untuk periode waktu tertentu:

1) Luaran Dermaga (Berth Output/ BTP);

2) Luaran Tenaga Kerja Bongkar Muat/ TKBM (Gang Output/ TGJ;

3) Luaran Gudang Penumpukan (Shed Output/ STP);

4) Luaran Lapangan Penumpukan (Yard Output/ YTP)

\section{Indikator Utilisasi}

Dipakai sebagai alat ukur efisiensi investasi pelayanan jasa pelabuhan yaitu utilisasi fasilitas dan peralatan, yang terdiri dari:

1) Utilisasi Dermaga (Berth Occupancy Ratio/ BOR);

2) Utilisasi Gudang (Shed Occupancy Ratio/ SOR);

3) Utilisasi Lapangan Penumpukan (Yard Occupancy Ratio/ YOR);

4) Utilisasi Peralatan (Equipment Utilization):

a) Peralatan Apung (Floatting Equipment);

b) Peralatan Bongkar-Muat (LoadingUnloading Equipment).

\section{Perkiraan Kunjungan Kapal dan Arus Barang}

Perkiraan jumlah kunjungan kapal dan arus

barang/ komoditas di masa yang akan datang secara kuantitatif sangat diperlukan sebagai pertimbangan untuk menambah peralatan dan SDM agar pelayanan tetap maksimal. 
Perkiraan yang akan datang secara kuantitatif dapat diterapkan apabila terdapat tiga kondisi sebagai berikut:

1) Tersedia informasi tentang masa lalu.

2) Informasi masa lalu dapat dikuantitatifkan dalam bentuk numerik (angka-angka).

3) Dapat diasumsikan bahwa aspek pola masa lalu akan terus berlanjut di masa yang akan datang (asumsi berkesinambungan).

\section{METODE PENELITIAN}

Diagram Alur Penelitian

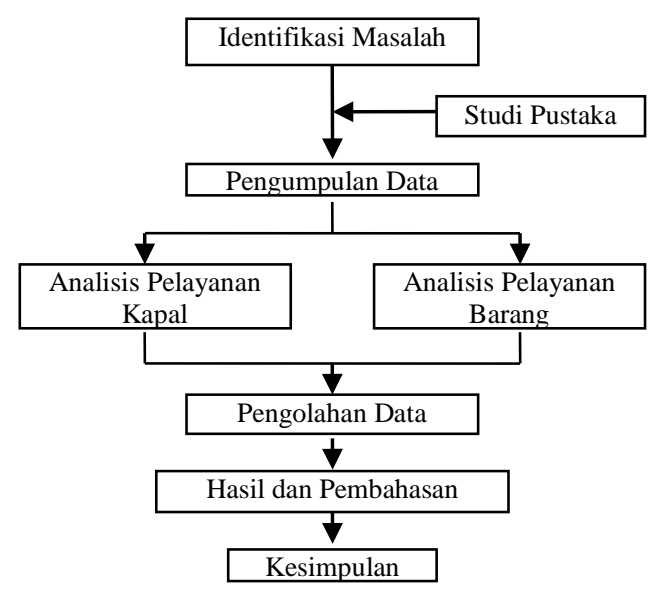

Gambar 3. Diagram Alur Penelitian

\section{HASIL DAN PEMBAHASAN \\ Pelabuhan Cilacap}

Berada di wilayah Kabupaten Cilacap, merupakan wilayah Provinsi Jawa Tengah bagian barat daya yang berbatasan langsung dengan Provinsi Jawa Barat. Kompetitor utama Pelabuhan Cilacap adalah Pelabuhan Tanjung Emas Semarang dan Pelabuhan Cirebon.

Wilayah hinterland mencakup wilayah Jawa Tengah yaitu Kab. Cilacap, Kab. Banyumas, Kab. Purbalingga, Kab. Banjarnegara, Kab. Kebumen dan Kab. Purworejo. Wilayah Provinsi Jawa Barat yaitu Kota/Kab. Tasikmalaya, Kab. Ciamis, Kab. Pangandaran, Kota Banjar. Wilayah DIY yaitu Kab. Bantul, Kab. Gunung Kidul, Kab. Kulon Progo, Kab. Sleman dan Kota Yogyakarta.

\section{Data Umum Pelabuhan \\ Keadaan Alam dan Geografis}

Pelabuhan Cilacap merupakan pelabuhan alam yang terletak pada posisi $07^{0} 44^{\prime} 55^{\prime \prime}$ LS dan $109^{0} 59^{\prime} 30^{\prime}$ BT. Strategis geografis cukup ideal karena terlindung Pulau Nusakambangan, sehingga aman dan tenang oleh besarnya ombak/gelombang Samudera Hindia.

Perairan dan alur masuk pelabuhan terdapat Singel Point Mooring (SPM), dermaga khusus
Pertamina Area 70, Crude Island Berth (CIB), dan dermaga Pasir Besi.

1) Tinggi gelombang maksimal di sekitar SPM : 2 meter

2) Kecepatan angin rata-rata : 2 knot Kecepatan arus rata-rata : 1.2 knot

3) Luas daerah kerja pelabuhan : 118,87 ha Luas daerah lingkungan kepentingan : 89,03 ha

4) Luas perairan pelabuhan : $11.583,05$ ha

5) Alur

Panjang : 9,5 mil

Lebar : 250 meter

Kedalaman efektif :

Buoy No.1 s/d No.17 : - 12 m.LWS

Buoy No.18 s/d No.23 : - 11 m.LWS

Donan s/d Karang Talun : - 6 m.LWS

Tanah dasar : Lumpur, tanah liat, pasir.

Kolam

Luas : $1.800 .000 \mathrm{~m}^{2}$ atau : 180 ha

Kedalaman : Tambatan umum:

Dermaga 1, 2, 3 : - 11 m.LWS

Dermaga 4 : - 9 m.LWS

Dermaga 5 dan $6:$ - 11 m.LWS

Kepentingan sendiri:

Pertamina CIB : - 12,5 m.LWS

Area 70 : $-11 \mathrm{~m} . \mathrm{LWS}$

Area 60 : -6 m.LWS

Pasir Besi : - 11 m.LWS

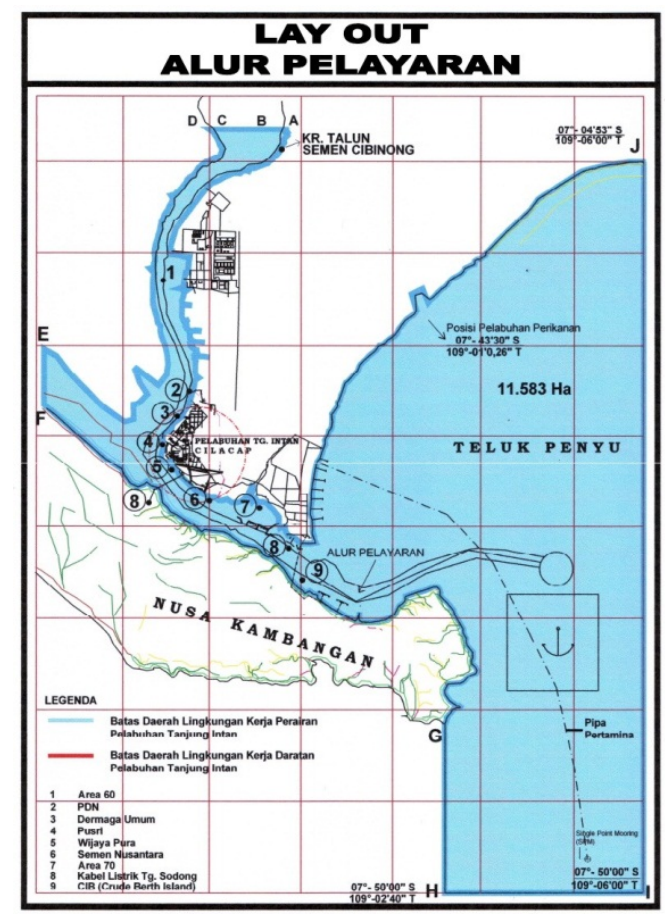

Gambar 4. Layout Alur Pelabuhan Cilacap 
Fasilitas Pelabuhan

\section{Dermaga}

Tabel 1. Dermaga Milik PT (Persero) Pelindo III

Cabang Cilacap

\begin{tabular}{|l|c|c|c|c|}
\hline \multicolumn{1}{|c|}{$\begin{array}{c}\text { Nama } \\
\text { Dermaga }\end{array}$} & $\begin{array}{c}\text { Pnjng } \\
\text { (m) }\end{array}$ & $\begin{array}{c}\text { Leb } \\
\text { (m) }\end{array}$ & $\begin{array}{c}\text { Dalam.LWS } \\
\text { m.LWa }\end{array}$ & $\begin{array}{c}\text { Lantai } \\
\text { (t/m) }\end{array}$ \\
\hline Dermaga 1 & 157 & 15 & -11 & 3 \\
Dermaga 2 & 124 & 25 & -11 & 3 \\
Dermaga 3 & 50 & 15 & -11 & 3 \\
Dermaga 4 & 72 & 18 & -9 & 3 \\
Dermaga 5 & 240 & 20 & -11 & 3 \\
Dermaga 6 & 120 & 15 & -11 & 3 \\
\hline Jumlah & $\mathbf{7 6 3}$ & & & \\
\hline Dermaga & 50 & 11 & 3 & 2,5 \\
Tunda/ & 10 & 4 & 7 & 1 \\
Pandu & & & & \\
Jetty minyak & & & & \\
(Bunker) & \multicolumn{5}{|c|}{$\mathbf{6 0}$} & & & \\
\hline Jumlah & $\mathbf{8 2 3}$ & & & \\
\hline Total & & & \\
\hline \multicolumn{5}{|c|}{ Sumber: PT. Pelindo III Cabang Cilacap } \\
\end{tabular}

Tabel 2. Dermaga Kepentingan Sendiri

\begin{tabular}{|l|c|c|}
\hline \multicolumn{1}{|c|}{ Nama Dermaga } & $\begin{array}{c}\text { Panjang } \\
\text { (m) }\end{array}$ & $\begin{array}{c}\text { Kedalaman } \\
\text { (m.LWS) }\end{array}$ \\
\hline Milik Pertamina & 24 & $-12,5$ \\
Jetty CIB 1 & 24 & $-12,5$ \\
Jetty CIB 2 & 24 & -11 \\
Jetty 1 Area 70 & 24 & -11 \\
Jetty 2 Area 70 & 23 & -11 \\
Jetty 3 Area 70 & 23 & -5 \\
Jetty 1 Area 60 & 23 & -6 \\
Jetty 2 Area 60 & 18 & -5 \\
Jetty 3 Area 60 & $\mathbf{1 8 3}$ & \\
\hline Jumlah & 11 & -4 \\
\hline Milik PT. Semen & 29 & -4 \\
Cibinong & 5 & -3 \\
Kade Nusakambangan & & \\
Kade Karang Talun 1 & $\mathbf{4 5}$ & \\
Kade Karang Talun 2 & & \\
\hline Jumlah & 50 & -11 \\
\hline Milik PT. Aneka & & \\
Tambang & 30 & -7 \\
Jetty Pasir Besi & & \\
\hline Milik PT. Pupuk & & \\
Sriwijaya & & \\
Jetty Pupuk Sriwijaya & & \\
\hline Total & & \\
\hline
\end{tabular}

Sumber: PT. Pelindo III Cabang Cilacap

Gudang dan Lapangan Penumpukan

Tabel 3. Gudang

\begin{tabular}{|c|c|c|c|c|}
\hline $\begin{array}{c}\text { Nama } \\
\text { Gudang }\end{array}$ & $\begin{array}{c}\text { Panjang } \\
(\mathbf{m})\end{array}$ & $\begin{array}{c}\text { Lebar } \\
(\mathbf{m})\end{array}$ & $\begin{array}{c}\text { Luas } \\
\mathbf{( m 2 )}\end{array}$ & $\begin{array}{c}\text { Lant } \\
\mathbf{a i} \\
\left(\mathbf{t} / \mathbf{m}^{\mathbf{2}}\right)\end{array}$ \\
\hline G.101 & 100 & 35 & 3.500 & 3 \\
G.201 & 60 & 30 & 1.800 & 3 \\
G.202 & 60 & 30 & 1.800 & 3 \\
\hline Jumlah & \multicolumn{3}{|c|}{$\mathbf{7 . 1 0 0}$} & \\
\hline \multicolumn{3}{|c|}{ Sumber: PT. Pelindo III Cabang Cilacap }
\end{tabular}

Tabel 4. Lapangan Penumpukan

\begin{tabular}{|c|c|c|c|c|}
\hline $\begin{array}{c}\text { Lapangan } \\
\text { Penumpukan }\end{array}$ & $\begin{array}{c}\text { Panjang } \\
(\mathbf{m})\end{array}$ & $\begin{array}{c}\text { Lebar } \\
(\mathbf{m})\end{array}$ & $\begin{array}{c}\text { Luas } \\
(\mathbf{m} 2)\end{array}$ & $\begin{array}{c}\text { Lantai } \\
\left(\mathbf{t} / \mathbf{m}^{2}\right)\end{array}$ \\
\hline L.101 & 108 & 36 & 3.888 & 2 \\
L.102 & 65 & 37 & 2.405 & 2 \\
L.103 & 90 & 40 & 3.600 & 2 \\
L.104 & 87 & 40 & 3.480 & 2 \\
L.105 & 30 & 29 & 870 & 2 \\
L.201 & 103 & 98 & 10.094 & 1,5 \\
L.202 & 67 & 42 & 2.824 & 2 \\
L.203 & 62 & 49 & 3.038 & 2 \\
\hline Jumlah & & & $\mathbf{3 0 . 1 9 9}$ & \\
\hline Parkir & & & 2.250 & 2 \\
\hline
\end{tabular}

Sumber: PT. Pelindo III Cabang Cilacap

\section{Alat-alat Apung dan Pemadam Kebakaran}

Milik PT (Persero) Pelindo III Cabang Cilacap:

Kapal Tunda Bima VI : 2.400 HP

Kapal Pandu MPI 013 : 400 HP

Kapal Kepil MPS 031 : 310 HP

Milik Pertamina:

KT. Patra Tunda : 4.200 HP

Kapal Tunda Mega : 3.000 HP

Kapal Tunda Miday : 3.000 HP

Kapal Tunda Mushol : 3.000 HP

Mobil damkar : 5.000 liter

Catatan:

Pelabuhan Cilacap termasuk pelabuhan wajib pandu dan wajib tunda:

Ukuran kapal wajib pandu $: \geq 500$ GT

Ukuran kapal wajib tunda : $\geq 70$ meter

\section{Alat-alat Bongkar Muat}

Tabel 5. Alat-alat Bongkar Muat

\begin{tabular}{|c|l|l|c|c|}
\hline No. & \multicolumn{1}{|c|}{ Pemilik } & $\begin{array}{c}\text { Jenis } \\
\text { Alat }\end{array}$ & $\begin{array}{c}\text { Kap. } \\
\text { (Ton) }\end{array}$ & Jml \\
\hline 1. & PT. Caravan & Forklift & 5 & 2 \\
& Nusantara & Dump & 6 & 1 \\
& & Truck & 8 & 8 \\
& & & 10 & 2 \\
& & & 11 & 2 \\
& & & 14 & 2 \\
& & Trailer & 45 & 10 \\
& & Forklift & 3 & 1 \\
\hline 2. & PT. Hasta Bayu & & 7,5 & 1 \\
\hline 3. & PT. Adhiguna & Forklift & 2,5 & 1 \\
& Putra & & 3,5 & 1 \\
\hline 4. & PT. Tembini Jaya & Forklift & 5 & 1 \\
\hline 5. & PT. Caraka & Forklift & 5 & 1 \\
& Bandar Guna & & & \\
\hline 6. & PT. Ampera Nusa & Dump & 6,5 & 11 \\
& Indah & Truck & 8,5 & 5 \\
& & & 11 & 1 \\
\hline 7. & PT. Pupuk & Forklift & 3,5 & 3 \\
& Sriwijaya & Shovel & 1,5 & 1 \\
\hline
\end{tabular}

Sumber: PT. Pelindo III Cabang Cilacap 


\section{Kunjungan Kapal}

Kapal-kapal yang berkunjung ke Pelabuhan Cilacap tidak terdapat kapal beroperasi secara reguler atau liner. Selama ini kapal-kapal yang berkunjung beroperasi secara tramper atau charter. Jumlah kapal yang berkunjung ke Pelabuhan Cilacap pada kurun waktu 2010-2014 hampir tidak mengalami peningkatan. Dari volume kapal (Gross Tonnage/ GT) secara agregat hanya sedikit tampak meningkat.

Kunjungan kapal didominasi oleh kapal-kapal tanker yang melayani kebutuhan angkutan komoditas minyak bumi baik minyak mentah maupun minyak produk olahan untuk PT. Pertamina Unit Pengolahan IV Cilacap. Kapal-kapal tanker tersebut melayani kegiatan angkutan minyak mentah baik dari sumber dalam negeri maupun dari luar negeri (impor), serta memuat produk olahan (BBM) untuk kebutuhan dalam negeri maupun untuk luar negeri (ekspor).

Kunjungan kapal pada tahun 2014 di Pelabuhan Cilacap sebanyak 1254 unit, terdiri dari kunjungan kapal-kapal tanker sebanyak 938 unit (710 pelayaran luar negeri dan 228 pelayaran dalam negeri) dan non-tanker 316 unit (207 pelayaran luar negeri dan 109 pelayaran dalam negeri). Kunjungan kapal-kapal tanker tersebut rata-rata setiap tahun diperkirakan mencapai 75\% dari seluruh kunjungan kapal, sedangkan no-tanker hanya 25\%.

Kunjungan kapal cargo jumlahnya relatif lebih sedikit. Kapal-kapal cargo (non-tanker) tersebut digunakan untuk mengankut komoditas curah kering seperti semen, gypsum, klinker, pasir besi, batu bara, biji gandum, pupuk, batu kapur/ limestone, dan hewan, serta komoditas dalam kemasan.

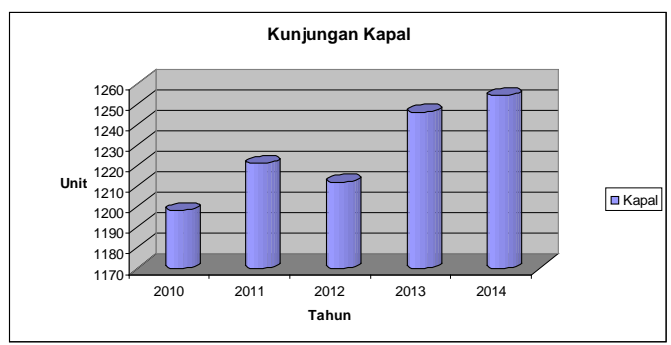

Gambar 5a. Grafik Kunjungan Kapal Tahun 2010 2014

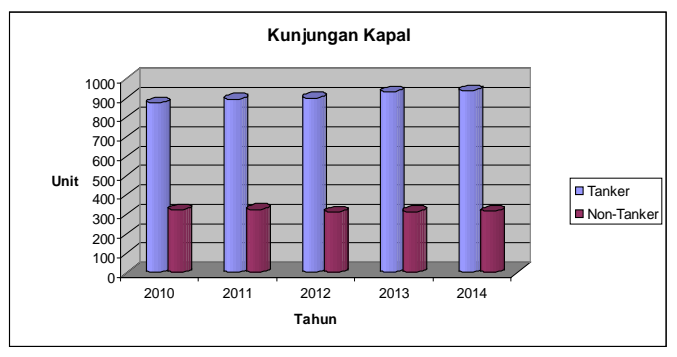

Gambar 5b. Grafik Kunjungan Kapal Tanker dan Non-Tanker Tahun 2010 - 2014

\section{Arus barang dan Komoditas Perdagangan}

Bongkar-muat komoditas perdagangan di Pelabuhan Cilacap didominasi oleh komoditas BBM. Komoditas tahun 2014 sebanyak 26.867.531 ton terdiri dari BBM sebanyak 21.799.091 ton (81 \%) dan non-BBM sebanyak 5.100 .518 ton (19 \%). Jumlah komoditas yang bongkar-muat di Pelabuhan Cilacap pada kurun waktu 2010-2014 hampir tidak mengalami peningkatan, bahkan cenderung mengalami penurunan.

Komoditas utama (unggulan) perdagangan dalam negeri (antar pulau) melalui Pelabuhan Cilacap terdiri dari hasil-hasil industri pertambangan, industri pertanian, dan hewan. Komoditas industri pertambangan tersebut adalah minyak bumi dan hasil produknya (BBM), limestone (batu kapur), batu bara, gypsum, klinker, pasir besi, dan semen. Komoditas industri pertanian terdiri dari pupuk dan minyak sawit.

Asal dan tujuan perdagangan antar pulau untuk komoditas non-BBM umumnya untuk wilayah Indonesia barat (Jawa, Sumatera, dan Kalimantan). Untuk komoditas BBM hampir mencakup seluruh wilayah Indonesia. PT. Pertamina Unit Pengolahan IV Cilacap memiliki kapasitas produksi 348.000 barrel/hari, memasok $34 \%$ kebutuhan BBM nasional.

Komoditas utama perdagangan luar negeri (ekspor-impor) terdiri dari BBM, biji gandum, gypsum, dan hewan (sapi). Asal dan tujuan komoditas perdagangan luar negeri adalah Asia (Singapura, Thailand, China, India, Banglades, Srilanka), Afrika, Timur Tengah, Australia, dan USA.

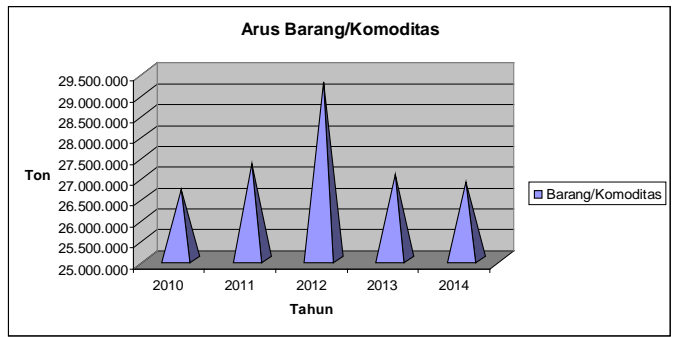

Gambar 6a. Grafik Arus Barang/Komoditas Tahun $2010-2014$

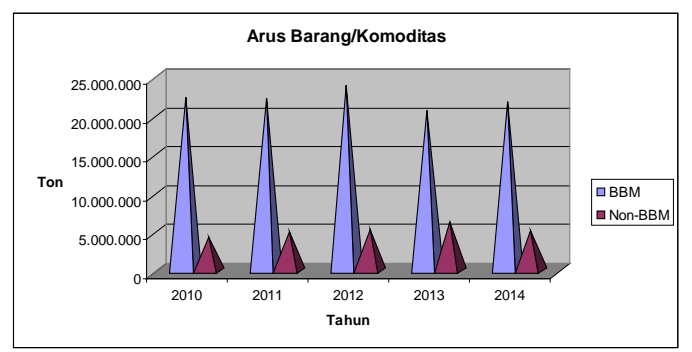

Gambar 6b. Grafik Arus Komoditas BBM dan NonBBM Tahun 2010 - 2014 


\section{Operasional Pelayanan}

Operasionan pelayanan di pelabuhan pada umumnya dibedakan atas 3 (tiga) macam yaitu, pelayanan terhadap kapal, produktivitas bonkarmuat, dan utilisasi fasilitas dan peralatan.

Tabel 6. Kinerja Pelayanan Kapal dan Barang Tahun 2010 - 2014

\begin{tabular}{|c|c|c|c|c|c|c|}
\hline \multirow{2}{*}{$\begin{array}{c}\text { Jenis } \\
\text { Pelayanan } \\
\end{array}$} & \multirow{2}{*}{ Sat } & \multicolumn{5}{|c|}{ Tahun } \\
\hline & & 2010 & 2011 & 2012 & 2013 & 2014 \\
\hline \multicolumn{7}{|l|}{ Kapal } \\
\hline $\begin{array}{l}\text { Samudera } \\
\text { - TRT }\end{array}$ & Jam & 162 & 157 & 138 & 127 & 111 \\
\hline Nusantara & & & & & & \\
\hline - TRT & Jam & 94 & 97 & 70 & 61 & 70 \\
\hline Tanker & & & & & & \\
\hline - TRT & Jam & 57 & 50 & 47 & 52 & 48 \\
\hline Barang & T/C & 24 & 28 & 31 & 23 & 24 \\
\hline Kemasan & $\mathrm{T} / \mathrm{G} / \mathrm{J}$ & 24 & 27 & 47 & 42 & 61 \\
\hline Curah & $\mathrm{T} / \mathrm{G} / \mathrm{J}$ & 29 & 22 & 61 & 88 & 96 \\
\hline
\end{tabular}

Sumber: PT. Pelindo III Cabang Cilacap

Tabel 7. Kinerja Fasilitas dan Peralatan Tahun $2010-2014$

\begin{tabular}{|c|c|c|c|c|c|c|}
\hline \multirow{3}{*}{$\begin{array}{l}\text { Kinerja/ } \\
\text { Utilisasi }\end{array}$} & \multirow{3}{*}{ Sat } & \multicolumn{5}{|c|}{ Tahun } \\
\hline & & 20 & 20 & 20 & 20 & 20 \\
\hline & & 10 & 11 & 12 & 13 & \\
\hline \multicolumn{7}{|l|}{ Fasilitas } \\
\hline Dermaga & $\mathrm{T} / \mathrm{M} /$ & & & & & \\
\hline - BTP & Th & 1.1 & 3,0 & 2,4 & 2,5 & 2.4 \\
\hline - BOR & $\%$ & 67 & 63 & 69 & 49 & 34 \\
\hline Gudang & $\mathrm{T} / \mathrm{M} /$ & & & & & \\
\hline - STP & Th & 10 & 16 & 14 & 13 & 12 \\
\hline - SOR & $\%$ & 22 & 11 & 16 & 15 & 19 \\
\hline Lapangan & $\mathrm{T} / \mathrm{M} /$ & & & & & \\
\hline Tumpuk & Th & & & & & \\
\hline - YTP & $\%$ & 0,4 & 0,6 & 0.4 & 0.5 & 0,5 \\
\hline - YOR & & 1,3 & 0,5 & 0,9 & 0.7 & 1,0 \\
\hline \multicolumn{7}{|l|}{ Yan } \\
\hline Barang & & & & & & \\
\hline $\begin{array}{l}\text { Tunda } \\
\text { Utilisasi }\end{array}$ & $\%$ & 29 & 29 & 57 & 66 & 61 \\
\hline $\begin{array}{l}\text { Pandu } \\
\text { Utilisasi }\end{array}$ & $\%$ & 44 & 42 & 45 & 40 & 42 \\
\hline $\begin{array}{l}\text { Kepil } \\
\text { Utilisasi }\end{array}$ & $\%$ & 48 & 19 & 31 & 21 & 24 \\
\hline
\end{tabular}

Sumber: PT. Pelindo III Cabang Cilacap

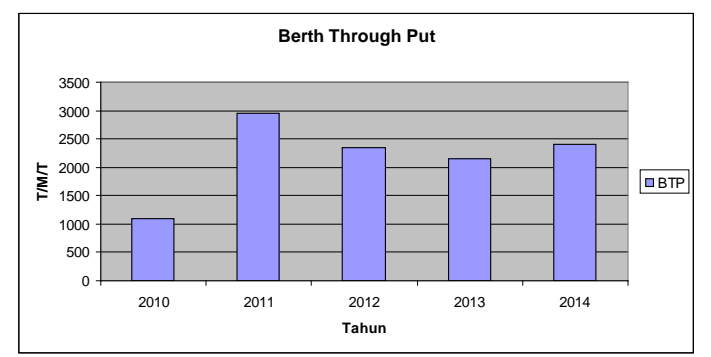

Gambar 7. Grafik Daya Pemakaian Dermaga (BTP) Tahun 2010 - 2014
Perkiraan kunjungan kapal dan arus barang di Pelabuhan Cilacap di masa yang akan datang dihitung berdasarkan metode rata-rata bergerak (multi moving average). Penghitungan tersebut berdasarkan informasi atau data masa lalu (tahun 2010 s/d 2014) dilakukan dengan menggunakan "forecast" pada microsoft excel. Hasil perkiraan kunjungan kapal dan arus barang pada tahun 2015 s/d 2019.

Dari hasil perkiraan terlihat bahwa kunjungan kapal untuk tahun 2015 s/d 2019 terjadi peningkatan. Sedangkan arus barang cenderung stabil walaupun terjadi sedikit peningkatan (kurang siqnifikan).

Tabel 8. Perkiraan Kunjungan Kapal dan Arus Barang Tahun 2015 - 2019

\begin{tabular}{|c|c|c|}
\hline Tahun & $\begin{array}{c}\text { Kunjungan } \\
\text { Kapal } \\
\text { (Unit) }\end{array}$ & $\begin{array}{c}\text { Arus Barang } \\
\text { (Ton) }\end{array}$ \\
\hline 2010 & 1198 & 26.678 .823 \\
2011 & 1221 & 27.301 .764 \\
2012 & 1212 & 29.256 .188 \\
2013 & 1246 & 27.052 .705 \\
2014 & 1254 & 26.867 .531 \\
2015 & 1267 & 27.469 .909 \\
2016 & 1281 & 27.482 .745 \\
2017 & 1295 & 27.495 .581 \\
2018 & 1308 & 27.508 .416 \\
2019 & 1322 & 27.521 .252 \\
\hline
\end{tabular}

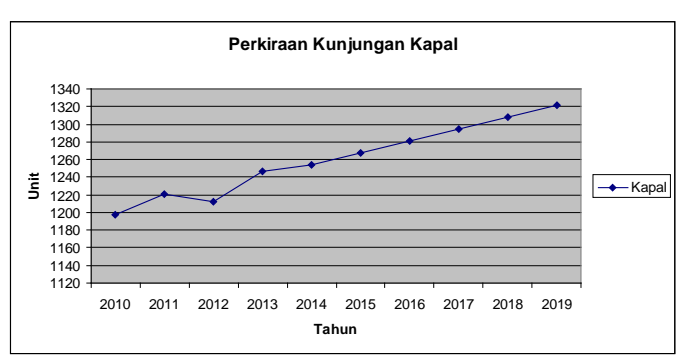

Gambar 9. Grafik Perkiraan Kunjungan Kapal Tahun 2015 - 2019

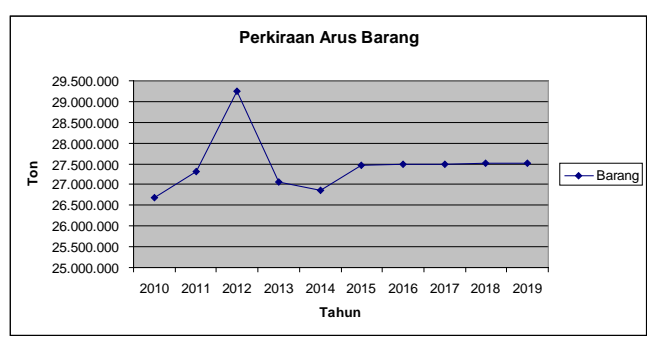

Gambar 10. Grafik Perkiraan Arus Barang Tahun 2015 - 2019

\section{Perkiraan Kunjungan Kapal dan Arus Barang 2015-2019}




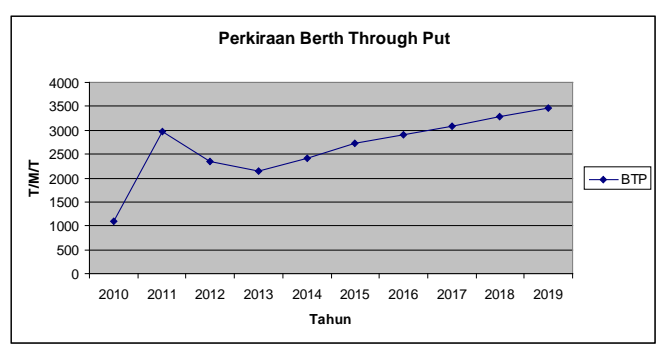

Gambar 11. Grafik Perkiraan Daya Pemakaian Dermaga Thn 2015 - 2019

\section{Meningkatkan Pelayanan Jasa Pelabuhan}

Untuk meningkatkan pelayanan jasa pelabuhan yang sedang dan akan dilakukan harus mempertimbangkan perkembangan jumlah kunjungan kapal, arus barang/ komoditas, dan kinerja pelabuhan, sebagai berikut:

1) Perkembangan jumlah kunjungan kapal relatif meningkat dari tahun ke tahun.

2) Perkembangan arus barang juga meningkat walaupun tidak siqnifikan.

3) Daya Pemakaian Dermaga (Berth Through Put/ BTP) yang cenderung meningkat.

4) Daya Pemakaian Gudang (Shed Through Put/ STP) cenderung stabil.

5) Daya Pemakaian Lapangan Penumpukan (Yard Through Put/ YTP) cenderung stabil.

Memperhatikan peningkatan kunjungan kapal, peningkatan arus barang, dan peningkatan daya pemakaian dermaga maka sudah seharusnya dikakukan peningkatan pelayanan jasa pelabuhan, yaitu dengan meningkatkan pelayanan kunjungan kapal dan meningkatkan pelayanan bongkar-muat barang.

Kunci peningkatan perbaikan pelayanan kapal terhadap Turn Round Time (TRT) khususnya komponen Waiting Time (WT), dan Berthing Time (BT).

1) Memperbaiki WT dilakukan dengan penyediaan peralatan kapal tunda, kapal pandu, kapal kepil, dan tenaga pandu yang memadai sehingga dapat memberikan palayanan yang maksimal dari outer buoy sampai dengan ke dermaga dan sebaliknya. Apabila pelayanan pandu dan tunda dapat dimaksimalkan sehingga terjadi penurunan TRT 1 (satu) jam untuk kapal dalam negeri dan 2 (dua) jam untuk kapal luar negeri.

2) Perbaikan pelayanan barang pada proses bongkar-muat terkait dengan BT. Peningkatan proses bongkar-muat barang setidaknya terkait dua hal yaitu ketersediaan Tenaga Kerja Bongkar-Muat (TKBM) dan peralatan bongkar-muat. Apabila TKBM dan peralatan bongkar-muat dimaksimalkan sehingga terjadi penurunan BT sampai 65 jam untuk kapal dalam negeri dan 90 jam untuk kapal luar negeri.

\section{Proyeksi Kebutuhan Fasilitas dan Peralatan}

Proyeksi fasilitas ini dibuat dengan membandingkan jumlah kunjungan kapal pada tahun 2014 sebanyak 1254 unit dengan perkiraan kunjungan pada akhir tahun 2019 sebanyak 1322 unit, maka terjadi peningkatan sebesar $6 \%$.

Tabel 9. Proyeksi Fasilitas Pelabuhan Tahun 2019

\begin{tabular}{|c|l|c|c|}
\hline No. & \multicolumn{1}{|c|}{ Fasilitas } & $\begin{array}{c}\text { Tahun } \\
\mathbf{2 0 1 4}\end{array}$ & $\begin{array}{c}\text { Proyeksi } \\
\text { Tahun } \\
\mathbf{2 0 1 9}\end{array}$ \\
\hline 1. & Dermaga & $823 \mathrm{~m}$ & $823 \mathrm{~m}$ \\
\hline 2. & Gudang & $7100 \mathrm{~m}^{2}$ & $7100 \mathrm{~m}^{2}$ \\
\hline 3. & $\begin{array}{l}\text { Lapangan } \\
\text { Penumpukan }\end{array}$ & $30199 \mathrm{~m}^{2}$ & $30199 \mathrm{~m}^{2}$ \\
\hline 4. & Kapal Tunda & 1 unit & 2 unit \\
\hline 5. & Kapal Pandu & 1 unit & 1 unit \\
\hline 6. & Kapal Kepil & 1 unit & 1 unit \\
\hline 7. & Crane & 1 unit & 1 unit \\
\hline 8. & Forklift & 1 unit & 2 unit \\
\hline 9. & $\begin{array}{l}\text { Pemadam } \\
\text { Kebakaran }\end{array}$ & 1 unit & 2 unit \\
\hline
\end{tabular}

Keterangan:

\begin{tabular}{|l|l|}
\hline \multicolumn{1}{|c|}{ Fasilitas } & \multicolumn{1}{c|}{ Keterangan } \\
\hline Dermaga & $\begin{array}{l}\text { Belum perlu penambahan, karena } \\
\text { BOR masih di bawah 75 \% }\end{array}$ \\
\hline Gudang & $\begin{array}{l}\text { Belum perlu penambahan, karena } \\
\text { SOR masih di bawah 75 \% }\end{array}$ \\
\hline $\begin{array}{l}\text { Lapangan } \\
\text { Penumpukan }\end{array}$ & $\begin{array}{l}\text { Belum perlu penambahan, karena } \\
\text { YOR masih di bawah 75 \% }\end{array}$ \\
\hline Kapal Tunda & Utilisasi mendekati 75\% \\
\hline Kapal Pandu & Utilisasi di bawah 75 \% \\
\hline Kapal Kepil & Utilisasi di bawah 75\% \\
\hline Crane & Utilisasi di bawah 75\% \\
\hline Forklift & Utilisasi mendekati 75\% \\
\hline $\begin{array}{l}\text { Pemadam } \\
\text { Kebakaran }\end{array}$ & Utilisasi mendekati 75\% \\
\hline
\end{tabular}

Selain proyeksi-proyeksi fasilitas di atas, yang tak kalah pentingnya adalah:

1) Penambahan tenaga pandu dari 2 (dua) menjadi 3 (tiga) orang.

2) Pengerukan alur secara berkala.

3) Berkomunikasi dengan para nelayan yang sering menebarkan jaring di sekitar alur pelabuhan.

\section{KESIMPULAN}

a. Sesuai letak geografis dan kondisi Pelabuhan Cilacap mempunyai keunggulan-keunggulan sebagai berikut:

1) Pelabuhan alam yang sangat tenang terlindung dari gangguan ombak.

2) Satu-satunya pelabuhan samudera yang berada di Pulau Jawa bagian selatan. 
3) Kedalaman kolam pelabuhan -11 LWS sangat memadai untuk kapal-kapal samudera.

b. Jumlah kunjungan kapal:

1) Jumlah kunjungan kapal meningkat ratarata $4,3 \%$ pertahun.

2) Kunjungan kapal di Pelabuhan Cilacap didominasi oleh kapal Tanker.

c. Arus barang cenderung meningkat rata-rata $1,2 \%$ pertahun.

1) Jenis-jenis komoditas yang dimuat adalah BBM, semen, klinker.

2) Jenis-jenis komoditas yang dibongkar adalah BBM mentah, biji gandum, pupuk, batubara, ternak, gypsum, minyak sawit, limestone, additive.

d. Pelayanan jasa pelabuhan:

1) Perbaikan waktu pelayanan kunjungan kapal akan meningkatkan jumlah kunjungan kapal.

2) Perbaikan waktu pelayanan bongkar-muat barang akan meningkatkan jumlah kunjungan kapal.

\section{REFERENSI}

\section{Peraturan:}

Undang-Undang Republik Indonesia Nomor 17 Tahun 2008 Tentang Pelayaran.

Peraturan Pemerintah Republik Indonesia Nomor 61 Tahun 2009 Tentang Kepelabuhanan.

\section{Buku-buku:}

Branch, Allan E. (1996). Elements of Shipping. Chapman \& Hall, London, UK.

Branch, Allan E. (1997). Elements of Port Operation and Management. Chapman \& Hall, London, UK.

Engkos Kosasih, Hananto Soewedo. (2012), Manajemen Perusahaan Pelayaran. PT. Raja Grafindo Persada, Jakarta

Lasse, D.A. (2014). Manajemen Kepelabuhanan. PT. Raja Grafindo Persada, Jakarta

Purba, Radiks. (1997). Angkutan Muatan Laut. Rineka Cipta, Jakarta.

Purwaka, Tommy H. (1993). Pelayaran Antar Pulau Indonesia. Bumi Aksara, Jakarta.

Salim, Abbas. (1995). Manajemen Pelayaran Niaga dan Pelabuhan. Pustaka Jaya, Jakarta.

Stopford, Martin. (2000). Maritime Economics. Routledge, London, UK.
Sugiyono. (2014). Metode Penelitian Kuantitatif Kualitatif dan $R \& D$. Alfabeta, Bandung.

Suyono, R.P.Capt. (2003). SHIPPING: Pengangkutan Intermodal Ekspor Impor Melalui Laut. PPM, Jakarta.

Triatmodjo, Bambang. (2007). Pelabuhan. Beta Offset, Yogyakarta. 